\title{
高強度ガラスレーザー用光パラメトリック過程 チャープパルス増幅法による前置増幅部の開発
}

\author{
吉田 英次 ${ }^{1}$, 宮地 絵理奈 ${ }^{1}$, 坚玉 了祐 ${ }^{1}$, 藤田 尚徳 ${ }^{1}$, 北川 米喜 ${ }^{2}$ \\ 1 大阪大学レーザーエネルギー学研究センター（テ565-0871 大阪府吹田市山田丘2-6) \\ 2光産業㓣生大学院大学 ( ₹431-1202 静岡県浜松市呉松町1955-1)
}

\section{Developments of a Front-End System for High-Intense Nd:Glass Laser Used in Optical Parametric Chirped Pulse Amplification}

\author{
Hidetsugu YOSHIDA, ${ }^{1}$ Erina MIYAJI, ${ }^{1}$ Ryosuke KODAMA, ${ }^{1}$ \\ Hisanori FUJITA, ${ }^{1}$ and Yoneyoshi KITAGAWA ${ }^{2}$ \\ ${ }^{1}$ Institute of Laser Engineering, Osaka University, 2-6 Yamada-oka, Suita, Osaka 565-0871 \\ ${ }^{2}$ The Graduate school for the Creation of New Photonics Industries, 1955-1 Kurematu-cho, Hamamatsu, Shizuoka $431-1202$
}

(Received July 28, 2005)

\begin{abstract}
We have constructed the front-end system using a broadband high-gain OPCPA for chirped pulse amplification. This system can deliver the output energy of $65 \mathrm{~mJ}$ with $6-\mathrm{nm}$ spectral width at a $1.053-\mu \mathrm{m}$ central wavelength. The stability of output energy was substantially improved compared with the $\mathrm{Ti}: \mathrm{Al}_{2} \mathrm{O}_{3}$ regenerative amplifier. These output parameters are appropriate as a seed of PW-class Nd:glass laser system.
\end{abstract}

Key Words: PW laser, Front-end system, High peak-power laser, Optical parametric chirped pulse amplifier, BBO crystal

1.はじめに

高利得可能なレーザー核融合方式として，“高速点火” 核融合は，その実現性が注目され，基礎研究が開始され た ${ }^{1-4)}$. 大阪大学レーザーエネルギー学研究センターで は，圧縮プラズマへの加熱実験を目指し，1998年に激光XII 号レーザーと同期して動作する $100 \mathrm{TW}$ (パルス幅0.5 ps)の 大型ガラスレーザーシステム (PW-モジュール)の開発後5), 2001年, 新たに前置増幅器部と大型パルス圧縮器部の新 設した後，PW級ガラスレーザーシステムが完成し， 2002 年より本格的稼働を開始した6,7).

本システムの活性媒質である Nd:ガラス ${ }^{8-11)}$ は, 熱特性 が劣るため高繰り返し動作には不向きであるが，蛍光ス ペクトル幅約 $20 \mathrm{~nm}$ 以上と比較的広く, 大口径ガラスレー ザー装置による高出力化 $\left(\mathrm{kJ}\right.$ 級) や高輝度化 $\left(10^{20} \mathrm{~W} / \mathrm{cm}^{2}\right.$ 以 上）が容易に達成可能である。一方, $\mathrm{Ti}^{-} \mathrm{Al}_{2} \mathrm{O}_{3}$ 極短パルス レーザーは, 高繰り返し動作 (数 $10 \mathrm{~Hz}$ 数 $\mathrm{kHz}$ ) が可能で あり，広範囲の発光スペクトル域700〜 $1100 \mathrm{~nm}$ をつ事 から, 数10 fsパルス幅の発生可能で, 最大出力数 Jが得ら れている12-17)。しかしながら，高出力 $\mathrm{Ti}: \mathrm{Al}_{2} \mathrm{O}_{3}$ は，上準位 寿命が室温約 $3 \mathrm{~ms}$ と速いため, 励起光には高出力YAGレー ザーの2倍高調波が必要である。また，飽和フルエンスが 小さく, 高品質・大型結晶育成が困難であるため, レー ザー出力はJ級が限界であり, $\mathrm{kJ}$ 級出力は困難である.
本稿では, 高出力, 高安定, 高コントラスト比が得ら れる極短パルスPW級ガラスレーザー用前置増幅器とし て，チャープパルス増幅方法として世界に先駆けて採用 した光パラメトリック過程によるチャープパルス増幅器 (OPCPA: Optical Parametric Chirped Pulse Amplification)の レーザー性能評価について述べる。

\section{2. 前置増幅器の構成配置}

本システムの構成配置図をFig. 1に示す.ガラスモード 同期発振器により発生された極短パルス光 (パルス幅約 $150 \mathrm{fs})$ は，8パス第1伸長器によりパルス幅を $10^{4}$ 倍の約 1.6 nsに伸長する。伸長後のパルスエネルギーは約 $100 \mathrm{pJ}(100$ $\mathrm{mW} / 100 \mathrm{MHz})$ と小さいので, OPCPA-Iにより数 $100 \mu \mathrm{J} レ へ ゙$ ルまで増幅する，増幅出力光は，8パス第2伸長器により 更に $3 \mathrm{~ns}$ 以上まで伸長した後, OPCPA-IIにより数 $10 \mathrm{~mJ}$ で増幅する ${ }^{18,19)}$. 回折格子の空間スペースの制限と第2伸 長器によるパルス幅可变機能を付加するため, 伸長器は2 段構成とした。

OPCPA-IIの出力は，ディスク型ガラス増幅器 (口径350 $\mathrm{mm})$ により十分なエネルギーを得た後, 大型パルス圧縮 器により再圧縮され，ピーク強度 $1 \mathrm{PW}$ レベル $(500 \mathrm{~J}, 500$ fs）を達成できる。また，本システムには，大型パルス圧 縮器と同等の小型パルス圧縮器部を設置し, 大型パルス 


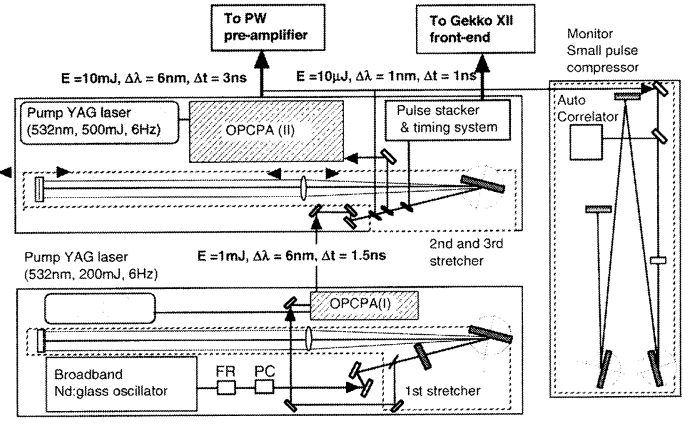

Fig. 1 Front-end system for PW glass laser.

圧縮器に対応したパルス幅測定を行う.

2.1 LD励起CWモード同期Nd：ガラスレーザー発振 器部

短パルス発振器部は20), 半導体可飽和吸収体を高速変 調素子として用いたLD励起モード同期ガラスレーザー (Time-Bandwidth社製)を採用した. Nd添加ガラス材料 は，蛍光スペクトル幅が20～30 nm と広いため，100 fs以 下のパルス発生 ${ }^{21,22)}$ には優れたレーザー媒質の一つであ り, $\mathrm{Nd}^{3+}$ の $800 \mathrm{~nm}$ 付近の強い吸収バンドは高出力LD励起 に最適である23)。大型ガラスレーザーのシード用に開発 されたLD励起モード同期ガラスレーザーは, Arレーザー やLD励起YAG - YVO 4 の2倍高調波励起の波長 $1 \mu \mathrm{m}$ 動作の $\mathrm{Ti}: \mathrm{Al}_{2} \mathrm{O}_{3}$ レーザーと比較すると, 低コスト, コンパクト, 取り扱いが容易であり，長寿命動作が可能である.

共振器長調整は，基準RF信号 $99.9800 \mathrm{MHz}$ とレーザー光 の一部を受光した高速pinダイオード出力を高速時間アン ド回路 (Time to clock)により, PZT素子(高速)执よびピエ ゾモーター(低速)によってフィードバック制御を行うこと により, 数ps精度での同期動作が可能である。レーザー性 能は，ピーク波長1056.5 nmの時, auto-correlatorにより測 定したパルス幅 (FWHM) $150 \mathrm{fs}$ は $\mathrm{sech}^{2}$ 関数によく一致し, スペクトル幅 (FWHM) $8.5 \mathrm{~nm}$ との積は，ほぼフーリエ限 界に近いパルス列が得られている24-26). 半導体可飽和吸収 素子を使用せず通常の高反射鏡によるCW動作では, 最大 $\mathrm{LD}$ 励起入力 $2.6 \mathrm{~W}$ の時レーザー出力 $200 \mathrm{mWが}$ 得られた。 受動モード同期発振は, 励起入力 $2.4 \mathrm{~W}$ の時レーザー出力 $120 \mathrm{~mW}$ 以上が得られた. モード同期可能な波長可変範囲 は, $1052 \mathrm{~nm}$ から $1067 \mathrm{~nm}$ である。

\section{2 第1, 2パルス伸長器部}

第1および第2伸長器の基本構成は, 回折格子と転送光 学素子からなる。回折格子はフォログラフィック法によ り製作し Au蒸着したもので, 溝本数は 1480 本 $/ \mathrm{mm}$ であ る. 発振器出力光は, 1パルス抽出用ポッケルスセルとFR 回転子を通過後, 回折格子面に対して47度で入射した。 本システムでは，パルス伸長器は1枚の回折格子による quadruple type（回折格子表面を8回反射）を使用した。回 折格子と球面レンズを所定の長さ $2100 \mathrm{~mm}$ に配置すること により，パルスの伸長度(パルス幅)が決まる．折り返し用 誘電体多層膜反射鏡は, レンズの焦点距離 $\mathrm{f}=3200 \mathrm{~mm}$ に 配置することで，空間チャープを補償する，高反射鏡に
より反射された光は再びレンズと回折格子によって反射 され後，2枚組の 45 度入射高反射鏡によって再び反射され る. 回折格子表面上でのレーザー光は, 上下一直線上に 等間隔で 8 点が並ぶように配置した. 同一光路を4回往復 したパルス光は，入射パルス幅 $150 \mathrm{fs}$ から約 $10^{4}$ 倍の約 1.6 nsまで伸長した後，45度入射高反射鏡によって取り出し， OPCPA-Iに入射した. 入射パワー $100 \mathrm{~mW}$ の時, 回折格子 の回折損失 (回折効率 0.95 の場合, 8 パス後の反射率 0.66 ) や他の光学素子の反射損失 (レンズの全反射防止膜透過率 0.9, 誘電体多層膜のクリッピング損失約 0.7$)$ 等により, 伸長後のレーザー出力は約 $40 \mathrm{~mW}$ (最大出力エネルギー 400 pJ)であった。第1伸長器後のスペクトル幅は，折り返し高 反射鏡のクリッピング損失により，8.2 nmから $7 \mathrm{~nm}$ となっ た。

第2伸長器は第1伸長器と同一配置であり, OPCPA-Iの増 幅出力パルス幅 $1.6 \mathrm{~ns} 3.2 \mathrm{~ns}$ まで伸長した。第2伸長器出 口のスペクトル幅は, 約 $6.5 \mathrm{~nm}$ であった。第2伸長器は, 折り返し高反射鏡とレンズを同一光学軸上で $\pm 10 \mathrm{~cm}$ 移動 可能であり, 最終の大型圧縮器部でのパルス幅を約 $500 \mathrm{fs}$ から数 $100 \mathrm{ps}$ ま゙可変できる。

\subsection{OPCPA-I, II増幅器部}

\subsubsection{OPCPA技術}

非線形光学結晶を用いた光パラメトリック増幅 (OPA) とチャープパルス光増幅 (CPA)を合わせもつOPCPA技術 による超短パルス光発生の研究 ${ }^{27-30)}$ は, 広带域波長 (紫外 から近赤外域)において, 高い利得が得られることから, 白色光シード光とOPAによって, 波長可変, 約 10 フェム ト秒レーザーを実現できる31,32)。また，結晶の熱蓄積が少 ない事から，現在市販されている $\mathrm{Ti}_{\mathrm{O}} \mathrm{Al}_{2} \mathrm{O}_{3} レ$ レ゙ーよりも 高品質, 高繰り返し, 高平均出カテーブルトップTW級 レーザーとなる可能性を秘めている。 また, 大型非線形 光学結晶(例えばKDP結晶)によるPW級OPCPAレーザーと して，0.35 PW(パルス幅85 fs) も報告されている ${ }^{33)}$.

前置増幅器部に採用したOPCPAシステムの主な長所を 列挙する.

(1) 利得狭帯化の影響が少なく, 広帯域スペクトル約 $100 \mathrm{~nm}$ 以上 (約 $20 \mathrm{fs}$ パルス幅)での増幅が可能である.

(2) 入射レーザー電界強度による位相差の影響 $(\mathrm{B}$ 積分 值)が少ない.

(3) ASE光やプリパルスが小さいため, 高いコントラス 卜比 (108以) が得られる.

（4）構成の簡易性から，レーザーの信頼性が高い.

（5）小さな利得長にもかかわらず，1段当たり $10^{3}$ 以上の 高利得が容易に得られる.

(6) 直接, 光から光へのエネルギー変換であり, 利得媒 質内への熱蓄積が小さい事から, 高品質ビームが得ら れる。

短所として, 増幅後のチャープパルス光のレーザー特 性は，励起光のレーザー性能に大きく依存する，空間 ビーム品質は励起光ビームの空間分布に依存し, 増幅光 の出力変動は励起光のパルス波形の時間的強度と変動に 依存する。このため, 励起レーザーには, 横モードは 
$\mathrm{TEM}_{00}$ モード, 励起パルス波形は単一縦モードQスイッチ パルスを採用し，パルス幅はチャープパルス光より長く しなければならない.また，励起光に対する増幅光の光 変換効率は，空間分布および時間波形の重複度に大きく 依存する，最大変換効率は，信号光とアイドラー光それ ぞれ30\%程度と報告されている28)。

OPCPA増幅器は, 第1伸長器後のチャープパルス光 1.6 nsを前置増幅するOPCPA-Iと, 第2伸長器後のチャープパ ルス光3 ns を飽和増幅するOPCPA-IIの2段構成である。

\subsection{2 高利得増幅器OPCPA-Iのレーザー特性}

OPCPA-Iは, Ti: $\mathrm{Al}_{2} \mathrm{O}_{3}$ 再生増幅器に代わる高利得増幅器 として採用した。Fig. 2にBBO結晶を用いたOPCPA-Iの実 験配置図を示す。非線形光学結晶BBO (type-I) は, LBOや KDP結晶に比べ非線形光学定数が大きいため, 高利得が 得られる事から採用した。BBO結晶は位相整合角22.8度に カットされ，各結晶寸法は， 1 段目 $5 \times 5 \times 15 \mathrm{~mm}^{3}$ と2段目 $5 \times 5 \times 18 \mathrm{~mm}^{3}$ である。励起用レーザーには，単一縦モー ドQスイッチYAGレーザーの2倍高調波 $532 \mathrm{~nm}$ を用い，最

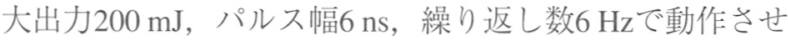
た. 各結晶への励起エネルギーは，入/2板と偏光子の組み 合わせによって調整した．励起光の口径 $7 \mathrm{~mm}(1 / \mathrm{e})$ は，2枚 の凸レンズの光学系 (焦点距離 $\mathrm{f}=500 \mathrm{~mm}$ と $\mathrm{f}=150 \mathrm{~mm}$ )に よって1/3.3倍の口径約 $2.2 \mathrm{~mm}(1 / \mathrm{e})$ まで縮小した. BBO結 晶表面のレーザー損傷を考慮し，最大励起強度を $700 \mathrm{MW} /$ $\mathrm{cm}^{2}$ とした。シード光であるチャープパルス光は，1パル ス当たりの最大エネルギー約 $400 \mathrm{pJ}$ ，パルス幅 $1.8 \mathrm{~ns}$, 中 心波長1053 nm，スペクトル幅7.2 nmである。ビーム径 は，ガリレオ光学系によって約 $1.3 \mathrm{~mm}$ まで縮小した。

OPCPA-Iの1段目および2段目の励起強度に対する全利得 特性をFig. 3に示す。各段の小信号利得は $10^{3} \sim 10^{4}$ であり, 飽和は観測されていない。1段目の励起強度 $430 \mathrm{MW} / \mathrm{cm}^{2} の$ 時約 $80 \mathrm{~nJ}\left(\right.$ 利得 $\left.2 \times 10^{2}\right)$ が得られ，2段目の最大励起強度 $620 \mathrm{MW} / \mathrm{cm}^{2}$ の) 時，最大出力約 $400 \mu \mathrm{J}$ (全利得約 $10^{6}$ ) が得ら れた。1段目の励起光とシード光は同軸上に入射し，2段 目の励起光は約1度ずらして入射し，信号光とアイドラー 光を分離した。

励起パルス，チャープパルスおよび増幅出力パルスの 空間強度分布㧍よび近視野像をFig. 4に示す。励起ビーム の空間強度分布は；ガウス型分布であり口径約 $2.2 \mathrm{~mm}(1 /$ e)である。励起光の空間強度分布による利得狭帯化によ り, シード光口径 $1.8 \mathrm{~mm}$ に対し, 増幅光口径 $1.3 \mathrm{~mm}$ ま゙

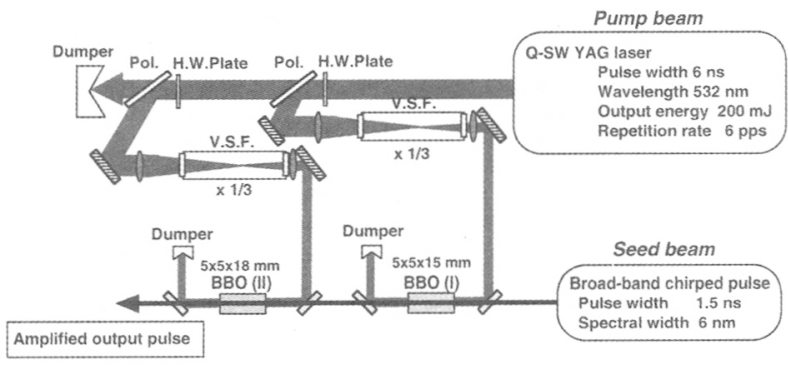

Fig. 2 Optical layout of OPCPA-I system.

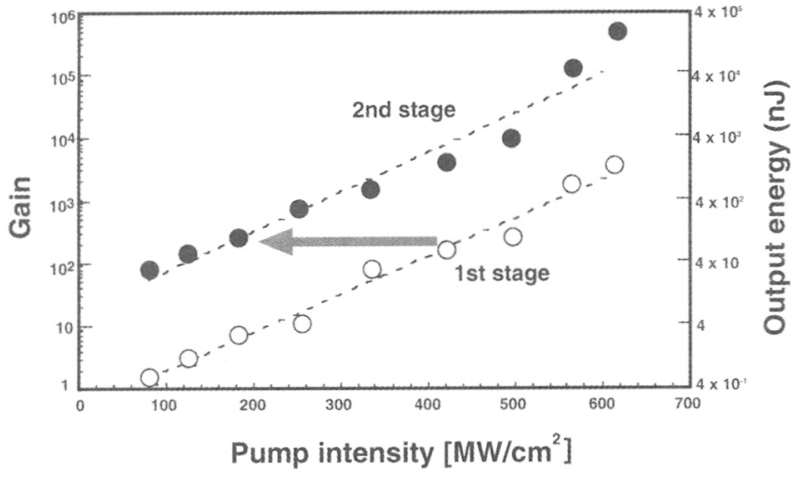

Fig. 3 Total gain results from the operation of stage 1 and 2 BBO crystals (OPCPA-I).

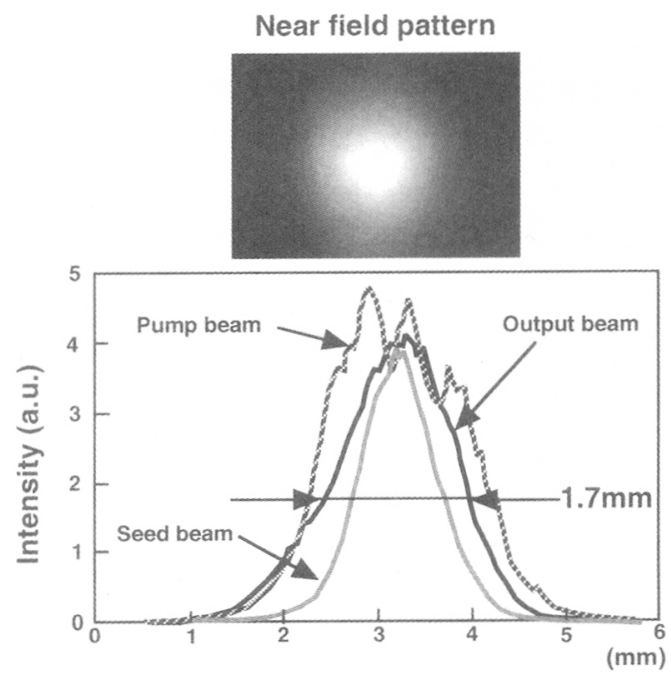

Fig. 4 Beam profiles of seed, pump and output pulse for OPCPA-I.

縮小した，励起光空間分布のピーク部の変調は，僅かな 利得飽和により緩和された結果，励起光分布を反映した ガウシアン型のTEM $\mathrm{TO}_{00}$ モードが得られた。

増幅利得に対するスペクトル幅およびパルス幅の関係

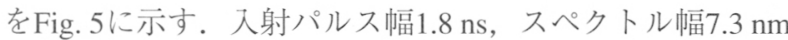
に対し，利得の増加と伴に緩やかに利得狭帯化が観測さ

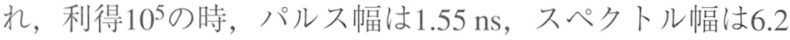
$\mathrm{nm}$ まで低下した。チャープパルス光 $(1.8 \mathrm{~ns})$ と励起パルス 光(擬ガウシアン型6ns)の時間ピーク值が合致した場合, 励起パルス波形の時間的強度変化により，チャープパル ス光の利得も変化する. 励起光の時間ジッター士 $1.8 \mathrm{~ns}$ は，増幅光のピーク強度変化では約 $20 \%$ まで低下するた め，總な利得狭带化が見られ，本実験結果は，計算結果 とほぼ合致した。利得狭帯化現象は，OPCPA-IIの利得飽 和による広带化により無視できる。狭帯化を抑制するに は，励起パルス波形のピーク強度を一定(台形波)にする必 要がある。

\subsection{3 主増幅器OPCPA-IIのレーザー特性}

OPCPA-IIは，第2伸長器後のチャープパルス光の主増幅 器として採用した。Fig. 6にBBO結晶を用いたOPCPA-IIの 実験配置図を示す。基本配置はOPCPA-Iと同じであるが, 


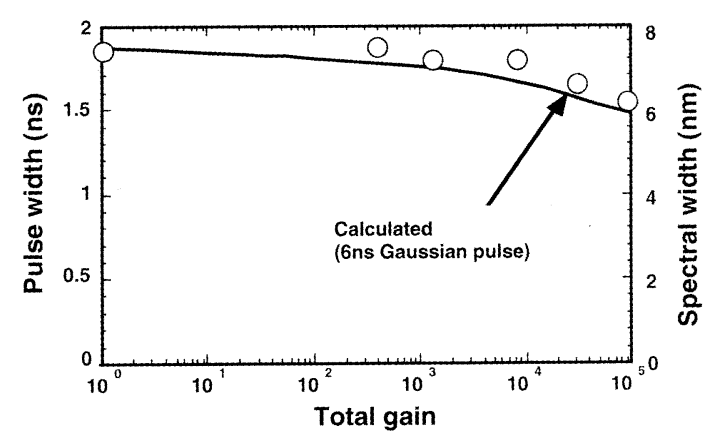

Fig. 5 Gain narrowing by pumping pulse shape for OPCPA-I.

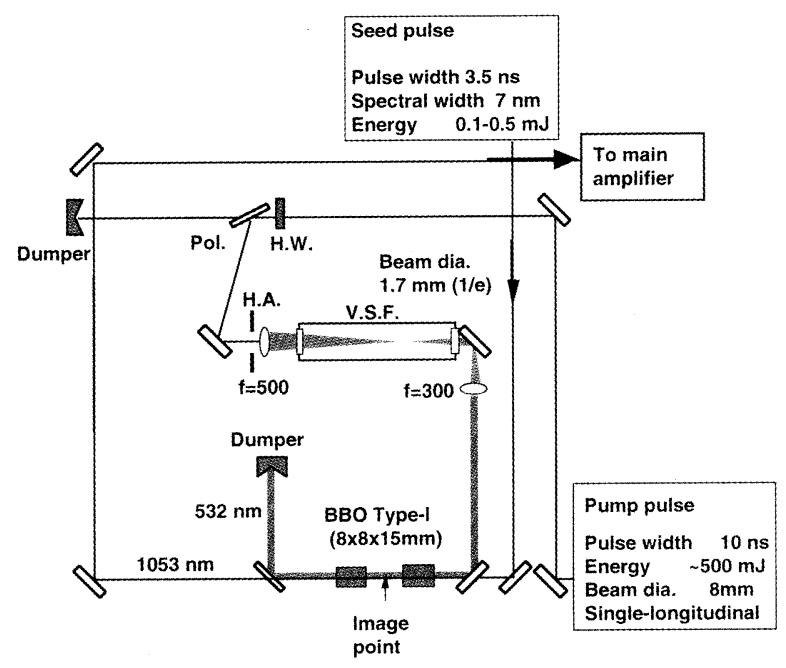

Fig. 6 Optical layout of OPCPA-II.

$2 つ の$ 結晶を直列に配置した，各結晶寸法は， $8 \times 8 \times 15$ $\mathrm{mm}^{3}$ である，励起用レーザーには，単一縦モードQスイッ チYAGレーザーの2倍高調波 $532 \mathrm{~nm}$ を用いた。励起光は最

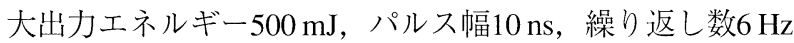
動作である.チャープパルス光は，パルス幅 3 ns以上であ るため，励起光のパルス幅を $10 \mathrm{~ns}$ とた，励起ビームの 口径 $8 \mathrm{~mm}(1 / \mathrm{e})$ は， $5.5 \mathrm{~mm}$ 口径のハードアパーチャーと像 転送光学系によって $1 / 1.5$ 倍の口径 $2 \mathrm{~mm}(1 / \mathrm{e})$ まで縮小し た。結像点は2個の結晶間に置いた。最大励起強度は, $800 \mathrm{MW} / \mathrm{cm}^{2}$ である。入射パルス性能は, 最大エネルギー 約 $600 \mu \mathrm{J}$ ，パルス幅 $3.2 \mathrm{~ns}$ 以上，中心波長 $1053 \mathrm{nm，スペク}$ トル幅 $7 \mathrm{~nm}$ 以上である。入射ビーム径は，約 $1.3 \mathrm{~mm}$ から $2 \mathrm{~mm}(1 / \mathrm{e})$ である.

Fig. 7は，励起強度に対するエネルギー利得を示す．励 起強度 $500 \mathrm{MW} / \mathrm{cm}^{2}$ の時, 小信号利得 7000 倍以上が得られ た。しかしながら，シード光エネルギー約 $20 \mu \mathrm{J}$ (入射強度 $\left.0.2 \mathrm{MW} / \mathrm{cm}^{2}\right)$ では, 励起強度 $450 \mathrm{MW} / \mathrm{cm}^{2}$ の時利得は約 500 倍まで低下した。 入射エネルギーを $580 \mu \mathrm{J}$ (入射強度 6.2 $\left.\mathrm{MW} / \mathrm{cm}^{2}\right)$ まで増加した場合, 励起強度 $950 \mathrm{MW} / \mathrm{cm}^{2}$ での利 得は90倍となった.シード光強度の増加と供にBBO結晶 の利得飽和を観測した. OPCPA-IIの2段結晶の全励起入ノ に対する出力特性をFig. 8に示す. 最大シード光エネル ギー約 $580 \mu \mathrm{J}$ の場合, 励起エネルギー約 $300 \mathrm{~mJ}$ の時最大出 力 $65 \mathrm{~mJ}$ が得られ, 総合効率約 $23 \%$ 達成した。アイド ラー光と合わせると，総合効率は約 $45 \%$ \%あった．励起

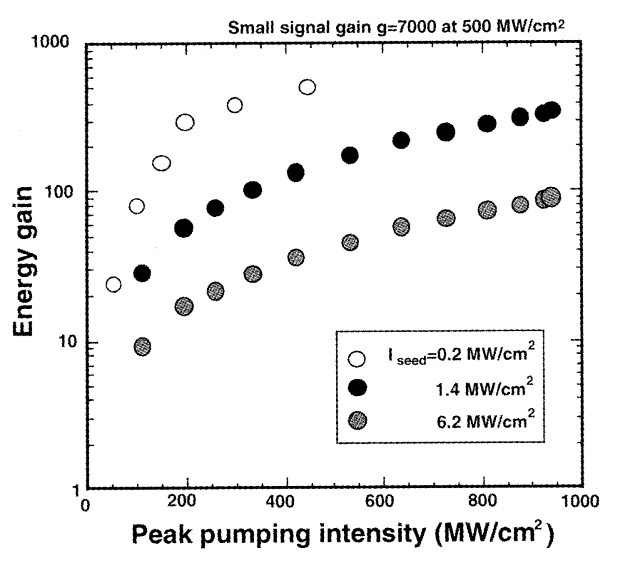

Fig. 7 Energy gain as a function of pumping intensity at three incident intensities.

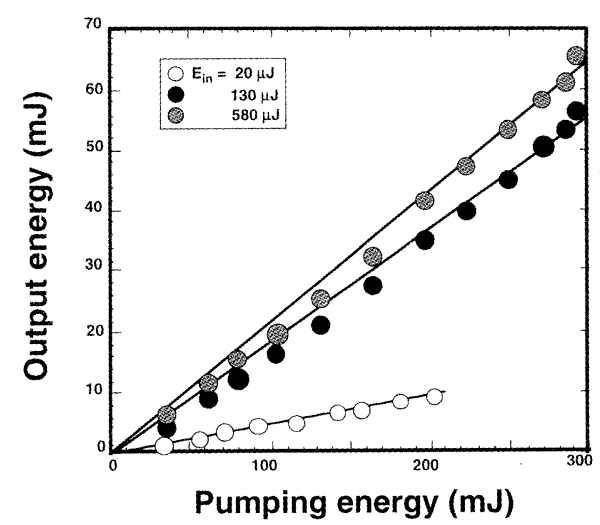

Fig. 8 Output energy as a function of pumping energy for OPCPA-II

およびシードビームの空間分布の重複度約 $65 \%$ と最大出 力時のパルス幅重複度84\%から求めた最大効率は約 $54 \%$ である，理論上の最大変換効率は約 $60 \%$ であり，比較的 良い一致をみた。

Fig. 9は，(a)励起パルスおよび入射パルス光，と (b) 各 増幅出力での空間パターンと強度分布を示す. 励起ビー ムおよびシード光の空間強度分布は擬ガウス型分布であ り，口径約 $2 \mathrm{~mm}(1 / \mathrm{e})$ と $1.7 \mathrm{~mm}(1 / \mathrm{e})$ である. 増幅光の空間 強度分布は, 出力エネルギーによって大きく変化した. 利得狭帯化により, 出力 $4.6 \mathrm{~mJ}$ 時の口径は入射パルス光に 比べ，縮小された。出力 $28 \mathrm{~mJ}$ では入射パルスとほぼ同じ 強度分布となったが, 出力エネルギーが増加すると, シード光空間分布のピーク強度の利得が飽和するのに対 し, 口径周辺部の利得増加する結果，スーパーガウス型 分布の $\mathrm{TEM}_{00}$ モードとなった. 出力 $56 \mathrm{~mJ}$ 時, 中央付近に 窪んだ空間強度分布は, 利得飽和の逆変換結果と予想さ れる．最大エネルギー出力時の口径は，励起光口径とほ ぼ同じである．増幅光の出力変動率は，線形増幅時は励 起強度に依存するため 8 \% 程度であったが，利得飽和と 伴に安定し, 最大出力時士 $3 \%$ 程度である。

エネルギー利得に対するスペクトル幅(パルス幅)の変 化と代表的なパルス波形をFig. 10に示す。入射エネルギー $580 \mu \mathrm{J}$ の時，入射スペクトル幅7 $\mathrm{nm}$ (パルス幅 $3.5 \mathrm{~ns}$ )は, 緩やかに増加し，最大利得約 90 でのスペクトル幅は 16.8 

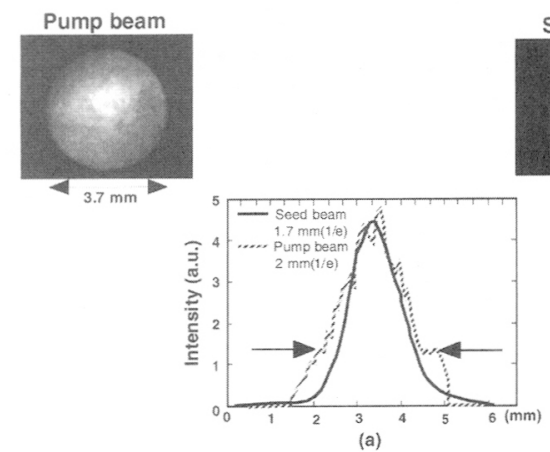

Output beam
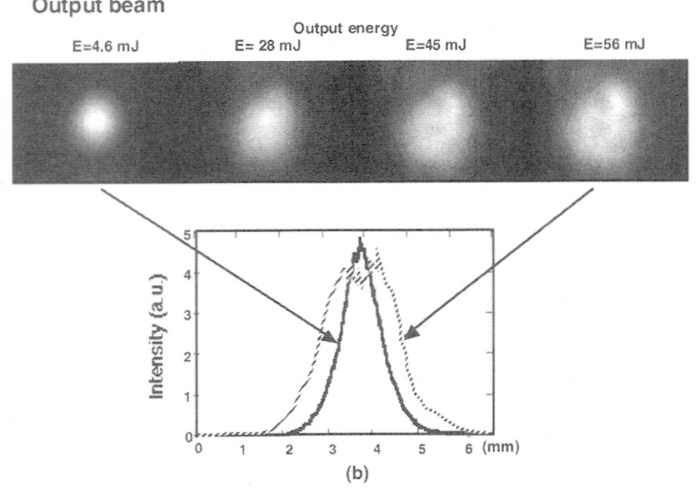

Fig. 9 (a) Beam profiles of seed and pumping pulse, and (b) amplified pulses for OPCPA-II.
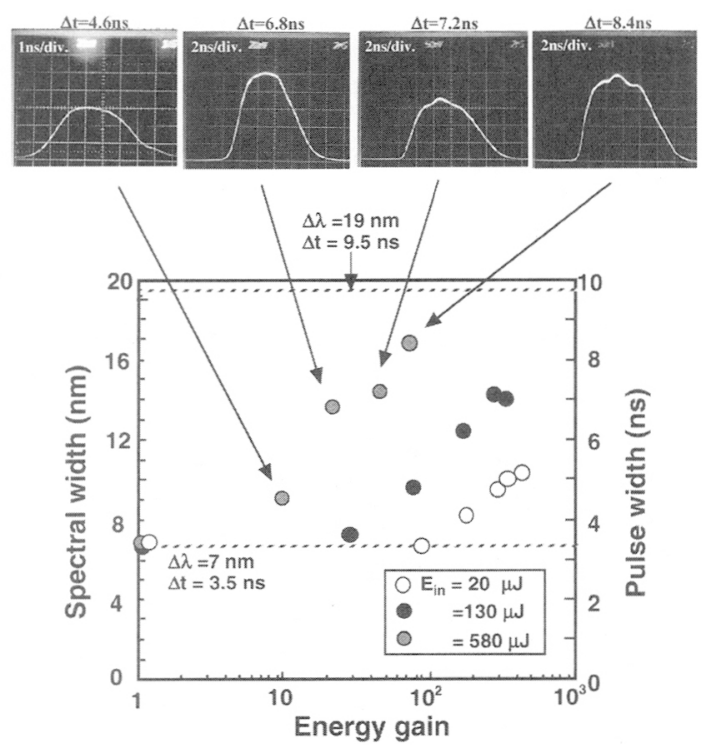

Fig. 10 Spectral width as a function of energy gain. Temporal profile recorded after saturated amplification.

$\mathrm{nm}$ (パルス幅 $8.4 \mathrm{~ns}$ ) となった。利得飽和によるスペクトル 幅の広帯域化は，空間分布と同様に見られた。最大スペ クトル幅は, 第2 伸長器光学部品のクリッピングと励起パ ルス幅により制限され，約 $20 \mathrm{~nm}$ である。入射エネルギー $20 \mu \mathrm{J}$ の時, OPCPA-I と同様に, 利得 10 程度では僅かな利 得狭带化が見られたが，利得100からスペクトル幅は増加 し，利得 500 ではスペクトル幅は約 $10.5 \mathrm{~nm}$ となった。増幅 時のパルス波形は，空間強度分布結果と同様に，パルス 波形のピーク波長1053 nmの利得飽和により，パルス波形 の立ち上がりおよび立ち下がり時間の利得が増加するた
め, 台形波となった。 OPCPAは, 小信号増幅領域では緩 やかな狭带化が見られるが，利得飽和増幅過程になる と, 緩やかなスペクトル幅の広带化が見られた。計算結 果から，飽和増幅が進行すると，中心波長付近の逆变換 過程によりスペクトル窪みが発生し，台形型のスペクト ル波形となる事が分かった。通常のCPA増幅では，反転分 布スペクトルによる増幅過程での帯域制限から利得狭带 化が見られるが, OPCPAではこれらの問題がなく，むし ろ入射スペクトルに比べ広带域化増幅が可能である。

\subsection{4ＯPCPAによるスペクトル制御性}

シード光を時間原点とし, 励起光の遅延時間による増 幅光のピーク強度とピーク波長変化をFig. 11に示す。ピー ク強度特性は，励起パルス幅に依存するため，ピーク強 度の時間幅は約 $10 \mathrm{~ns}$ であ。 また，シード光の中心波長 を線形に変化するため, 励起パルス光の遅延時間によっ て要求される中心波長に設定できる.

よって，励起パルスの波形整形技術によって，任意の 増幅パルス波形を整成できる。また，増幅パルス光の出 力安定度は, 励起パルス波形の時間ジッターや波形振幅 度によって，大きく依存していることを意味している。

また，利得の増加とスペクトル幅の広带域化の方法と して，多段結晶による増幅を行った。4段直列配置のBBO 結晶による増幅実験を行い，スペクトルを測定した結果 をFig. 12に示す。入射スペクトル幅的 $7 \mathrm{~nm}$ に対し，各結晶 の位相整合角を任意の増幅波長 $(1046 ， 1050 ， 1056 ， 1061$ $\mathrm{nm}$ )に合致させることにより，18.5 nmの広帯域(回折格子. のクリッピングにより制限)まで増幅することができた。

1個のBBO結晶を用いた場合でも，利得带域幅 $100 \mathrm{nmが}$ 能であり，数個のBBO結晶による数100 nmの広帯域高利 得増幅が可能である。

\section{4 小型パルス圧縮器部 (パルス幅測定器部)}

小型パルス圧縮器は, PW級レーザー用大型パルス圧縮 器 (ビーム口径 $500 \mathrm{~mm}$, 回折格子寸法 $950 \mathrm{~mm}$ ) と同等の光 学配置で構成した。PWレーザーは，第2伸長器部のレン

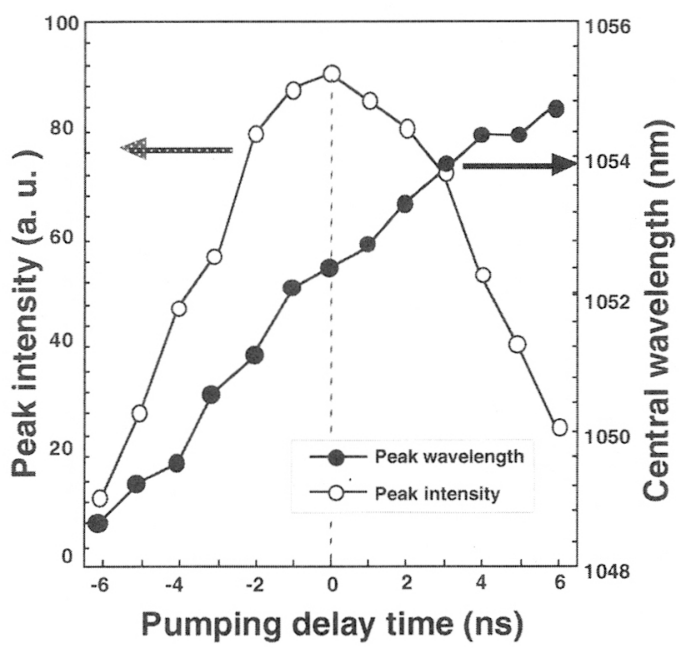

Fig. 11 Wavelength turning by pumping laser timing. 


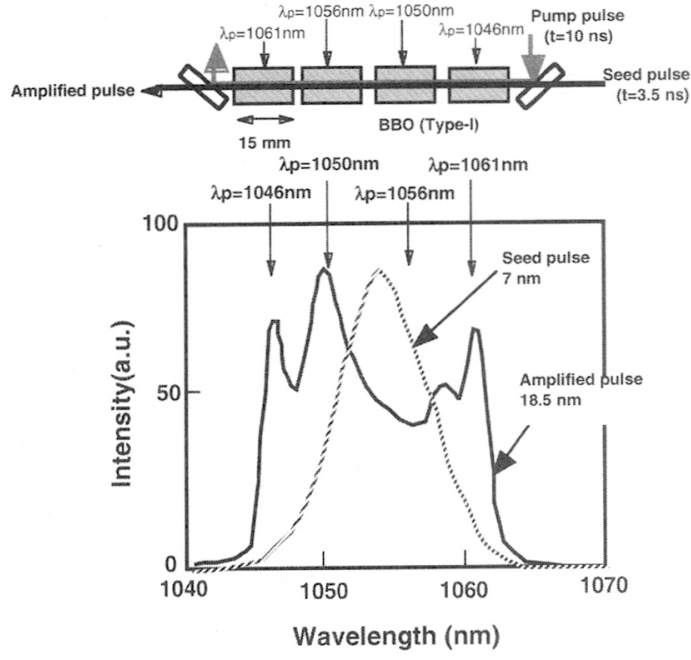

Fig. 12 Spectral broading of amplified pulse using four BBO crystals.

ズと高反射鏡の移動距離によって，最終圧縮後のパルス 幅を500 fsから数 $100 \mathrm{ps}$ まで可変可能であり, 大型パルス 圧縮後のパルス幅モニターとして設置した.

OPCPA-IIによって増幅されたチャープパルス光は，口 径15 mmに拡大された後, 対称に配置された2枚の回折格 子によって圧縮した。レーザー光は, 回折格子面に対し て47度で入射した。回折格子間隔は大型圧縮器 $9.6 \mathrm{~m}$ に対 し，小型圧縮器の回折格子間隔は $4.8 \mathrm{~m}$ とし，2枚組の 45 度 入射高反射鏡によって 2 往復した後，圧縮パルス光はク リップ用反射鏡によって取り出した。圧縮パルス光は, auto-correlatorによるパルス幅およびスペクトル幅測定を 行った。

ピーク波長1054 nmの時，auto-correlatorにより測定した パルス幅(FWHM) およびスペクトル特性をFig. 13に示す. パルス幅 $350 \mathrm{fs} \mathrm{fsech}^{2}$ 関数によく一致し，スペクトル幅 (FWHM) 5.3 nmとの積は, ほぼフーリエ限界に近いパル ス幅が得られている。入射スペクトル幅7 $\mathrm{nm}$ に対し，2番 目の回折格子のスペクトルクリッピングによって $5.3 \mathrm{~nm}$ 制限された。スペクトル幅 $5.3 \mathrm{~nm}$ は, ガラス増幅器の利得 狭带化により，大型圧縮器部でのスペクトル幅〜 $3.5 \mathrm{~nm}$ に 比べ広い。圧縮パルスのペデスタルパルスは, スペクト

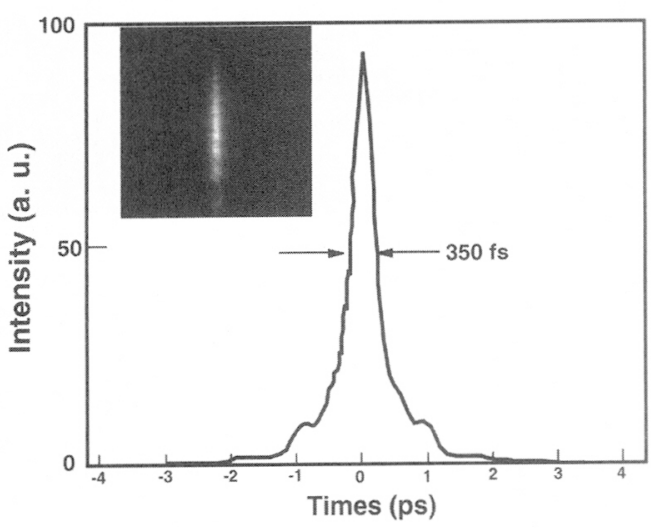

Fig. 13 Recompressed pulse intensity by single-shot autocorrelation.
ルクリッピングによる成分である。OPCPAを用いた増幅 後の圧縮パルスのプリパルス比測定では，OPCPAの総合 利得と同じ $10^{-8}$ 以下であることを確認した ${ }^{34)}$ 。一方， Ti: $\mathrm{Al}_{2} \mathrm{O}_{3}$ 再生増幅器の場合, 切り出し用ポッケルスセルのSN 比により制限され，10-3程度であった。

\section{3.まとめ}

高出力, 高安定, 高コントラスト比が得られる極短パ ルスPW級ガラスレーザー用前置増幅器の開発を行った。

発振器出力光は, 2 段構成のパルス伸長器により, 発振 器パルス幅の約 $2 万$ 倍の $3.2 \mathrm{~ns}$ まで伸長し, チャープパルス 光とした。増幅器には，世界に先駆けてOPCPA技術を採 用し，利得の狭带化なしで所定のチャープパルス増幅( ス ペクトル幅 $6 \mathrm{~nm}$ 以上，パルス幅 $3 \mathrm{~ns}$ 以上) が可能となっ た.出力パルス光のプリパルス比は10-8以下であり, $\mathrm{TEM}_{00}$ モード，高効率23\%で最大出力 $65 \mathrm{~mJ}$ が安定に得ら れた。

今回，採用したOPCPA技術は，簡易で高利得，高いコ ントラスト比が得られる事から, $\mathrm{Ti}_{\mathrm{O}} \mathrm{Al}_{2} \mathrm{O}_{3}$ 再生増幅器より 優れている。また, 高利得大型非線形結晶(例えばKDP結 晶)を用いたOPCPA装置により, 現状の $\mathrm{Ti}_{\mathrm{A}} \mathrm{Al}_{2} \mathrm{O}_{3}$ レーザー では不可能な高品質ビーム，数10フェム卜秒，数PW級の 出現が可能となる。このため, 高速点火慣性核融合用高 強度レーザー, 超高密度プラズマ生成による高輝度X線発 生やX線レーザー励起, 中性子源が比較的小型システムで 実現可能である。

\section{謝 辞}

詳細にわたる御指導，御助言を賜りました大阪大学 レーザーエネルギー学研究センター中塚 正大教授, 宮永 憲明教授，三間 图興センター長，井澤靖和前センター長 山中 龍彦元センター長に深く感謝致します。

\section{参考文献}

1) M. Tabak, J. Hammer, M. E. Glinsky, W. L. Kruer, S. C. Wilks, J. Woodworth, E. M. Campbell, and M. D. Perry: Phys. Plasmas 1 (1994) 1626

2) R. Kodama, K. Takahashi, K. A. Tanaka, M. Tsukamoto, H. Hashimoto, Y. Kato, and K. Mima: Phy. Rev. Letts. 77 (1996) 4906.

3) R. Kodama, P. A. Norreys, K. Mima, A. E. Dangor, R. G. Evans, H. Fujita, Y. Kitagawa, K. Krushelnick, T. Miyakoshi, N. Miyanaga, T. Norimatsu, S. J. Rose, T. Shozaki, K. Shigemori, A. Sunahara, M. Tampo, K. T. Tanaka, Y. Toyama, T. Yamanaka, and M. Zepf: Nature 412 (2001) 798.

4) R. Kodama, H. Shiraga, Y. Toyama, S. Fujioka, H. Azechi, H. Fujita, H. Habara, T. Hall, Y. Izawa, T. Jitsuno, Y. Kitagawa, K.M. Krushelnick, K. L. Lancaster, K. Mima, K. Nagai, M. Nakai, H. Nishimura, T. Norimatsu, P. A. Norreys, S. Sakabe, K. T. Tanaka, A. Youssef, M. Zepf, and T. Yamanaka: Nature 418 (2002) 933.

5) Y. Kato, Y. Kitagawa, K A. Tanaka, R. Kodama, H. Fujita, T. Kanabe, T. Jitsuno, H. Shiraga, H. Takabe, M. Murakami, H. Nishimura, and K. Mima: Plasma Phys. Control. Fusion 39 (1997) A145.

6) Y. Kitagawa, H. Fujita, R. Kodama, H. Yoshida, T. Jitsuno, S. Sakabe, K.A. Tanaka, H. Nishimura, Y. Izawa, K. Mima, and T. Yamanaka: CLEO Pacific Rim 2001 Tech. Digest MC2-1 (2001) 
I-70.

7) Y. Kitagawa, H. Fujita, R. Kodama, H. Yoshida, T. Jitsuno, S. Sakabe, K. A. Tanaka, H. Nishimura, Y. Izawa, K. Mima, and T. Yamanaka: IFSA 2001 Tech. Digest. IFSA1272 (2001) 71.

8) Y. Beaudoin, C. Y. Chien, J. S. Coe, J. L. Tapie, and G. Mourou Opt. Lett. 17 (1992) 865.

9) C. Rouyer, E. Mazataud, I. Allais, A. Perry, S. Seznec, C. Sauteret, G. Mourou, and A. Migus: Opt. Lett. 18 (1993) 214.

10) K. Yamakawa, H. Shiraga, Y. Kato, and C. P. Barty: Opt. Lett. 16 (1991) 1593.

11) K. Yamakawa, H. Sugio, H. Daido, M. Nakatsuka, Y. Kato, and S. Nakai: Opt. Commun. 112 (1994) 37.

12) K. Yamakawa, M. Aoyama, Y. Akahane, J. Ma, N. Inoue, H. Ueda, and H. Kiriyama: レーザー研究 30 (2002) 747.

13) V. Babnoud and F. Salin: Appl. Phys. B 70 (2000) 165.

14) J. K. Kmetec, J. J. Macklin, and J. F. Young: Opt. Lett. 16 (1991) 1001.

15) A. Sullivan, H. Hamster, H. C. Kapteyn, S. Gordon, W. White, H. Nathel, R. J. Blair, and R. W. Falcone: Opt. Lett. 16 (1991) 1406.

16) C. Le. Blanc, G. Grillon, and J. P. Chambaret: Opt. Lett. 18 (1993) 140.

17) K. Yamakawa and C. P. J. Barty: IEEE J. Sel. Topics Quantum. Electron. 6 (2000) 658.

18) H. Yoshida, E. Ishii, K. Sawai, R. Kodama, H. Fujita, Y. Kitagawa, S. Sakabe, Y. Izawa, T. Yamanaka, and M. Fujita: CLEO 2001 Tech. Digest. CMT7 (2001) 99.

19) H. Yoshida, E. Ishii, K. Sawai, R. Kodama, H. Fujita, Y. Kitagawa, S. Sakabe, Y. Izawa, T. Yamanaka, and M. Fujita: CLEO Pacific Rim 2001 Tech. Digest MC3-2 (2001) I-80.
20）吉田 英次，児玉 了祐，藤田 尚德，加藤 義章，三間 图興： レーザー研究 27 (1999) 291

21) C. Spielmann, F. Krausz, T. Brabec, E. Wintner, and A. J. Schmidt: Appl. Phys. Lett. 58 (1991) 2470.

22) F. X. Kartner, D. kopf, and U. Keller: Ultrafast Phenomena IX (Springer-Verlag, Berlin) (1994) 458

23) S. Basu and R. L. Byer: Opt. Lett. 13 (1988) 458.

24) U. Keller, D. A. B. Miller, G. D. Boyd, T. H. Chiu, J. F. Ferguson, and M. T. Asom: Opt. Lett. 17 (1992) 505.

25) U. Keller: Appl. Phys. Lett. B58 (1991) 2470.

26) D. Kopf, F. X. Kartner, U. Keller, and K. J. Weingarten: Opt. Lett. 20 (1995) 1169.

27) A. Dubietis, G. Jonusauskas, and A. Piskarskas: Opt. Commun. 88 (1992) 437.

28) I. N. Ross, P. Matousek, M. Towrie, A. J. Langley, and J. L. Collier: Opt. Comm. 144 (1997) 125.

29) J. Collier, C. Hermandez-Gomez, I. N. Ross, P. Matousek, C. N. Danson, and J. Walczak: Appl. Opt. 38 (1999) 4786.

30) I. N. Ross, J. Collier, P. Matousek, C. N. Danson, D. Neely, R. M. Allott, D. A. Pepler, C. Hermandez-Gomez, and K. Osvay: Appl. Opt. 39 (2000) 2422

31) T. Wilhelm, J. Piel, and E. Riedle: Opt. Lett. 22 (1997) 1494.

32) A. Shirakawa, I. Sakane, and T. Kobayashi: Opt. Lett. 23 (1998) 1292.

33) O. Chekhlov, J. L. Collier, I. N. Ross, P. Bates, M. Notley, W. Shaikh, C. N. Danson, D. Neely, P. Matousek, and S. Hancock: CLEO Europe 2005 Tech. Digest CG1-6 (2005) 42.

34) H. Yoshida, E. Ishii, R. Kodama, H. Fujita, Y. Kitagawa, Y. Izawa, and T. Yamanaka: Opt. Lett. 28 (2003) 257. 